\title{
Comparison of satisfaction with postgraduate training in anaesthesiology in European countries and Ukraine: survey of more than $\mathbf{2 0 0}$ clinicians.
}

\author{
M.M. Pylypenko1, I.V. Kyselova1, S.I. Vorotyntsev², S.O. Dubrov³, Yu.Yu. Kobelyatskyy \\ ${ }^{1}$ P.L. Shupyk National Medical Academy of Postgraduate Education, Kyiv, Ukraine \\ 2 Zaporizhzhya State Medical University, Zaporizhzhya, Ukraine \\ ${ }^{3}$ O.O. Bogomolets National Medical University, Kyiv, Ukraine \\ 4 Dnipropetrovsk State Medical Academy, Dnipropetrovsk, Ukraine
}

\section{Background and Goal of Study}

One of the main features of the Ukrainian system of postgraduate training in anaesthesiology is its extremely short duration - 2 years compared to 4-6 years in the Europe.

The aim of our study is to identify and compare a level of satisfaction in postgraduate training and the readiness for independent working after residency among anaesthesiologists in Ukraine and in Europe.

\section{Materials and Methods}

During European Congress "Euroanaesthesia-2015" Ukrainian delegation participated in an educational project "National Village" and represented the system of postgraduate education in Ukraine.

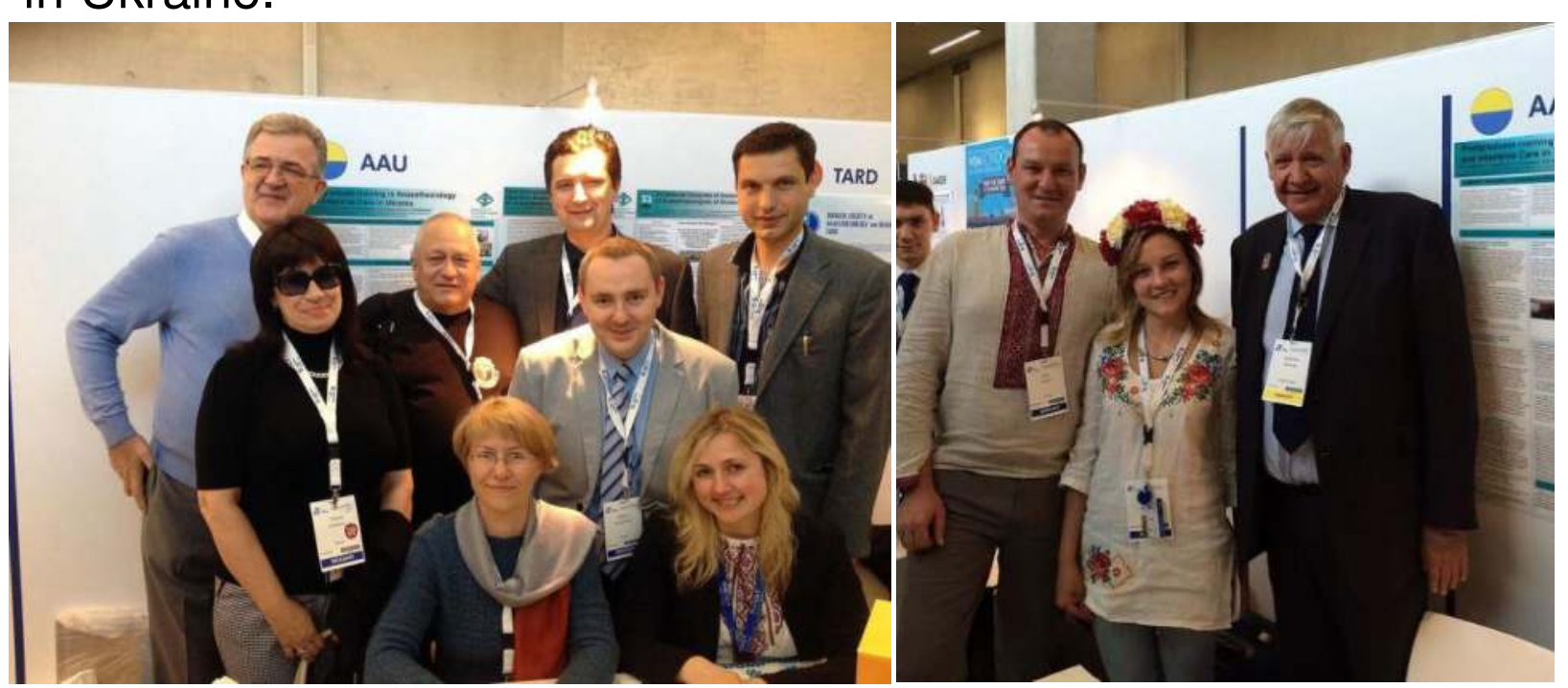

Additionally, at the Ukrainian stand we offered delegates a short survey, which consisted of 5 questions about their postgraduate training (in each estimation was from 1 to 10 points). The same survey was conducted in Ukraine.

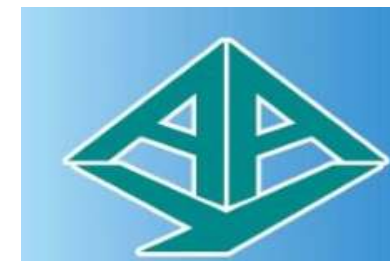

Short SURVEY

about anaesthesia-intensive care residency training in your country

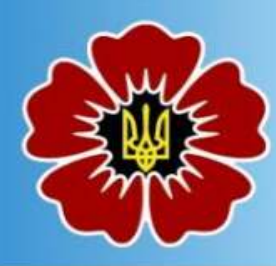

Background: Well known that in the 21-st century almost over the whole Europe residency in anaesthesiology lasts 6 years. In Ukraine residency still lasts 2 years but due to economic situation, it is hard to change this. We have interviewedUkrainian anaesthesiologists about the term and satisfaction of their training in residency and received interesting results.

Aim: To look for a snapshot of the European anaesthesiologists'view on their residency and to compare with Ukrainian colleagues.

Methods: Please complete short, blinded survey. Thanks in advance!

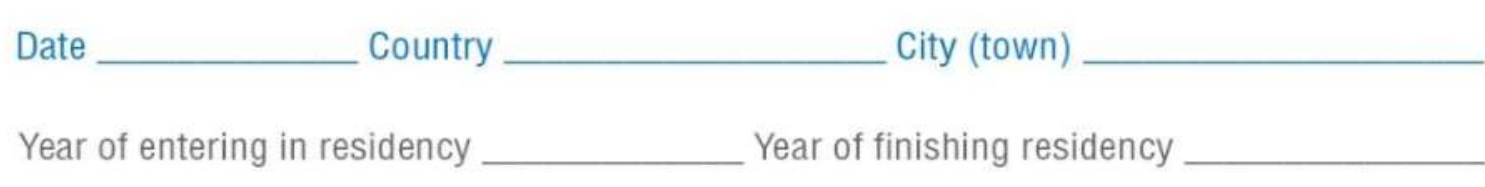

Are you working mainly in Operation Room (OR) in ICU or both

. Please provide a global evaluation note (from 1 : very poor to 10 : excellent) for the satisfaction of your residency training___ Comment

2. Please estimate your readiness for independent work just after residency training (from 1to 10) ___ Comment

3. If you would choose the term of your residency training HOW MANY YEARS you prefer to spend in the training? Comment

4. Please imaginea situation (as it currently in Ukraine) where during your residency training you would not receive the salary but have to pay for your education by your own. How many years you WOULD PREFER to spend on the training IF YOU HAVE TO PAY YOUR OWN? Comment

5. Do you agree that residency training should be separate for anaesthesiology and intensive care?

\section{Results}

Among 156 anaesthesiologists who were surveyed on ESA congress, 105 were from Europe and 51 - guests from other continents. The control group consisted of 105 Ukrainian clinicians.

Term of work in a specialty anaesthesiology including residency training was about 17,7 $\pm 11,2$ years for European respondents and 15,0 \pm 8,7 years for Ukrainian.

Term of their residency was indicated as an average 4,5 years by European doctors and 1,9 years by Ukrainian.

European anaesthesiologists have evaluated their satisfaction from postgraduate training as $7,8 \pm 1,8$ points on a 10-points scale, similar as Ukrainian ones - 7,5 $\pm 2,0$ points.

The readiness to independent working along right after finishing residency was evaluated by European doctors as 8,2 $\pm 1,7$ points, whereas the readiness of Ukrainian respondents was lower $-7,1 \pm 2,1$ ( $p<0,001$, t-test).

$32 \%$ among European and only $18 \%$ of Ukrainian doctors preferred to have the separate residency in anaesthesiology and in intensive therapy.

\begin{tabular}{|c|c|c|c|c|c|c|c|}
\hline & $\begin{array}{c}\text { Work in } \\
\text { Operation } \\
\text { Room (OR) } \\
\text { only (\% of } \\
\text { respond.) }\end{array}$ & $\begin{array}{c}\text { Work in } \\
\text { both ICU } \\
\text { and OR (\% } \\
\text { of respond.) }\end{array}$ & $\begin{array}{c}\text { 1.Satisfactio } \\
\text { n of your } \\
\text { residency }\end{array}$ & $\begin{array}{c}\text { 2.Readiness } \\
\text { for } \\
\text { independen } \\
\text { many years } \\
\text { twork }\end{array}$ & $\begin{array}{c}\text { 4. If you pay for } \\
\text { residency, how } \\
\text { reany years you to } \\
\text { rrefer to spend in } \\
\text { spend for } \\
\text { training }\end{array}$ & $\begin{array}{c}\text { 5.Do you agree } \\
\text { with the } \\
\text { trining IF YOU } \\
\text { HAVE TO PAY PAY } \\
\text { roUR OWN? } \\
\text { residency on } \\
\text { Anaestesiology } \\
\text { and Intensive } \\
\text { Terapy (Yes, \%) }\end{array}$ \\
\hline $\begin{array}{c}\text { ESA responders } \\
\text { (M) }\end{array}$ & $44 \%$ & $53 \%$ & 7,8 & 8,2 & 4,7 & 2,3 & $32 \%$ \\
\hline $\begin{array}{c}\text { Ukrainian } \\
\text { responders (M) }\end{array}$ & & 7,5 & 7,1 & 2,8 & 2,2 & $18 \%$ \\
\hline
\end{tabular}

\section{Discussion}

The same level of satisfaction with postgraduate training in European countries and in Ukraine was a surprise for us, considering the difference of the duration of residency. It could be explained by some overestimation of the residency training satisfaction by Ukrainian doctors.

Slightly (but statistically significantly) higher level of readiness to independent working after residency of European doctors could justify longer duration of postgraduate training.

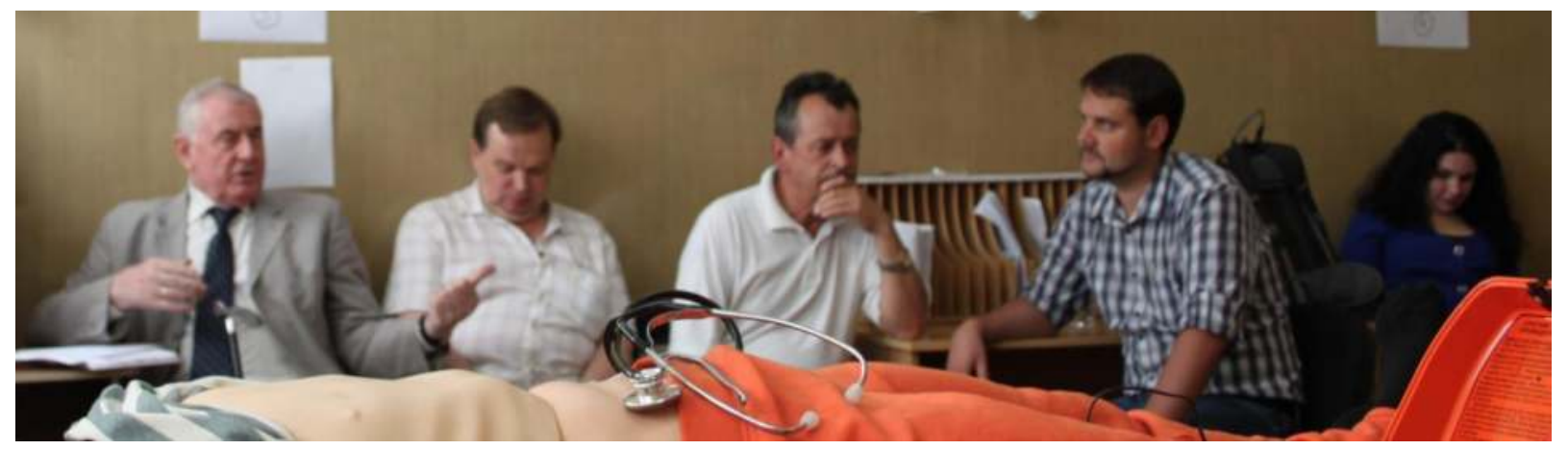

\section{Conclusion}

European anaesthesiologists have a longer duration of residency and their readiness to independent working after training is higher, but the satisfaction of postgraduate training are similar. 